\title{
Evaluation of the size segregation of elemental carbon (EC) emission in Europe: influence on the simulation of EC long-range transportation
}

\author{
Ying Chen ${ }^{1,2}$, Ya-Fang Cheng ${ }^{2}$, Stephan Nordmann ${ }^{2,3}$, Wolfram Birmili ${ }^{1,3}$, Hugo A. C. Denier van der Gon ${ }^{4}$, \\ Nan Ma ${ }^{1,2}$, Ralf Wolke ${ }^{1}$, Birgit Wehner ${ }^{1}$, Jia Sun ${ }^{1}$, Gerald Spindler ${ }^{1}$, Qing Mu ${ }^{2}$, Ulrich Pöschl ${ }^{2}$, Hang Su${ }^{2}$, and \\ Alfred Wiedensohler ${ }^{1}$ \\ ${ }^{1}$ Leibniz-Institute for Tropospheric Research, Leipzig, Germany \\ ${ }^{2}$ Multiphase Chemistry Department, Max Planck Institute for Chemistry, Mainz, Germany \\ ${ }^{3}$ German Environment Agency, Dessau-Roßlau, Germany \\ ${ }^{4} \mathrm{TNO}$, dept. Climate, Air, and sustainability, Utrecht, the Netherlands
}

Correspondence to: Ya-Fang Cheng (yafang.cheng@mpic.de) and Alfred Wiedensohler (ali@tropos.de)

Received: 25 September 2015 - Published in Atmos. Chem. Phys. Discuss.: 6 November 2015

Revised: 28 January 2016 - Accepted: 1 February 2016 - Published: 17 February 2016

\begin{abstract}
Elemental Carbon (EC) has a significant impact on human health and climate change. In order to evaluate the size segregation of EC emission in the EUCAARI inventory and investigate its influence on the simulation of EC longrange transportation in Europe, we used the fully coupled online Weather Research and Forecasting/Chemistry model (WRF-Chem) at a resolution of $2 \mathrm{~km}$ focusing on a region in Germany, in conjunction with a high-resolution EC emission inventory. The ground meteorology conditions, vertical structure and wind pattern were well reproduced by the model. The simulations of particle number and/or mass size distributions were evaluated with observations at the central European background site Melpitz. The fine mode particle concentration was reasonably well simulated, but the coarse mode was substantially overestimated by the model mainly due to the plume with high EC concentration in coarse mode emitted by a nearby point source. The comparisons between simulated EC and Multi-angle Absorption Photometers (MAAP) measurements at Melpitz, Leipzig-TROPOS and Bösel indicated that the coarse mode EC (ECc) emitted from the nearby point sources might be overestimated by a factor of 2-10. The fraction of ECc was overestimated in the emission inventory by about $10-30 \%$ for Russia and 5-10\% for Eastern Europe (e.g., Poland and Belarus). This incorrect size-dependent EC emission results in a shorter atmospheric life time of EC particles and inhibits the long-range trans-
\end{abstract}

port of EC. A case study showed that this effect caused an underestimation of $20-40 \%$ in the EC mass concentration in Germany under eastern wind pattern.

\section{Introduction}

Elemental carbon (EC) and black carbon (BC) are characterized by their strong radiation absorbing effect (Hansen et al., 2000; Jacobson et al., 2000; Cheng et al., 2008, 2009; Bond et al., 2013) and adverse health effects (Pope et al., 2009; Bond et al., 2013). For climate change, EC is the second strongest contributor to current global warming with a total radiative forcing of about $+1.1 \mathrm{~W} \mathrm{~m}^{-2}$, just after the carbon dioxide (Bond et al., 2007; Ramanathan and Carmichael, 2008). Globally, biomass burning (40\%), fossil fuel combustion $(40 \%)$ and biofuels combustion $(20 \%)$ are the major source of EC emission (Ramanathan and Carmichael, 2008). The EC particles freshly emitted from incomplete combustion have sizes around $100 \mathrm{~nm}$ (Rose et al., 2006). The EC particles size segregation information is also very significant for climate, long-range transport and health effect. These fine mode (sub-micron) EC particles are much more important than the coarse mode, since fine particles have longer lifetime than coarse particles (Petzold and Kärcher, 2012; Croft et al., 2014). They have higher chances of accumulating in 
the atmosphere and participate in long-range transportation (e.g. Himalayan and arctic region), and furthermore contributing to the global-scale climate forcing. Previous studies showed that EC long-range transport and deposition on ice could contribute to the glacier melting in Himalayan (Ming et al., 2008) and arctic regions (McConnell et al., 2007; Ramanathan and Carmichael, 2008). The EC deposition on snow and ice could change the surface albedo, absorbs solar radiation and causes positive climate forcing. Furthermore, regarding the effect on health, fine EC particles could translocate from lung to blood with the adsorbed toxic matters (e.g.: heavy metal) inducing many diseases (Pope et al., 2009; Meister et al., 2012). The definitions of EC and BC depend on how these species were measured. $\mathrm{BC}$ is used for an optical determination and EC for a thermographic measurement method (Nordmann et al., 2013; Vignati et al., 2010). However, the discrepancies between EC and BC are usually disregarded, and they are interchangeable in the modeling studies (Vignati et al., 2010). Nordmann et al. (2013) showed that the EC and BC were well correlated in the German Ultrafine Aerosol Network (GUAN) sites measurements. Nordmann et al. (2013) and Nordmann et al. (2014) indicated that EC in the model can be used as the best approximation of BC in modelling study.

The emission inventory is one of the key factors for the evaluation of the EC climate effect with model (Vignati et al., 2010). The IPCC (IPCC, 2013) reported BC radiative forcing of $0.4(0.05-0.8), 0.2$ and $0.04(0.02-0.09) \mathrm{W} \mathrm{m}^{-2}$ from fossil fuel combustion, biomass burning and deposition on snow, respectively. The uncertainties in the evaluation of $\mathrm{BC}$ global and regional climate effect may be due to uncertainties in $\mathrm{BC}$ mass concentrations, which are derived from BC emission and removal processes (Koch et al., 2009). Emissions of carbonaceous aerosols are notoriously uncertain (Denier van der Gon et al., 2015). The European Environment Agency report (EEA, 2013) indicated that it was almost impossible to evaluate overall uncertainty at EU level. The uncertainty for EC emissions is at least $50 \%$ on global scales, and a factor of 2 to 5 on regional scale (Ramanathan and Carmichael, 2008). The uncertainty is originated not only from an instrument measurement uncertainty but also the conditions under which the emission factor measurements take place (Denier van der Gon et al., 2015). Global emission inventories of EC have been published (e.g.: Bond et al., 2004; Lamarque et al., 2010) without size segregation information. An emission inventory for UNECE-Europe of EC (EUCAARI 42-Pan-European Carbonaceous aerosol inventory) has been published with a $1 / 8^{\circ} \times 1 / 16^{\circ}$ high resolution and separated size mode $\left(\mathrm{PM}_{1}, \mathrm{PM}_{1-2.5}\right.$ and $\left.\mathrm{PM}_{2.5-10}\right)$ (Visschedijk and Denier van der Gon, 2008). UNECE-Europe includes the EU28 countries and Albania, Armenia, Azerbaijan, Belarus, Bosnia Herzegovina, Georgia, Moldova, Macedonia, Norway, Russia Federation, Serbia and Montenegro, Switzerland, Turkey and Ukraine (Denier van der Gon et al., 2015). The EUCAARI inventory consists of anthropogenic emissions by country for the 10 Source Nomenclature for Air Pollution (SNAP) sectors: energy transformation, small combustion sources, industrial combustion, industrial processes, extraction of fossil fuels, solvent and product use, road transport, non-road transport, waste handling, and agriculture (Visschedijk and Denier van der Gon, 2008).

Numerous works have evaluated the performance of EC emission and transport models for Europe. Koch et al. (2009) evaluated 17 global models and found out that 13 of 17 models over-estimate EC in Europe. Stern et al. (2008) compared five models result with northern Germany observations, and none of the models could reproduce the high EC concentration at the central Europe background station Melpitz. Genberg et al. (2013) pointed out that the EMEP MSC-W model underestimates the EC concentration at Melpitz may because the low model resolution can not represent local effects (like point source). Nordmann et al. (2014) pointed out that the EUCAARI inventory may underestimate the Eastern European EC emission by a factor of about 2, but not considering the size segregation uncertainty of EC emission and its influence on transportation.

In this work, a high-resolution WRF-Chem simulation was set up in conjunction with the EUCAARI EC inventory, focusing on the central Europe region. The modelling result was evaluated by the aerosol and $\mathrm{EC} / \mathrm{BC}$ in situ measurements from GUAN and HOPE-Melpitz Campaign. The EC emission fraction for coarse $\left(\mathrm{PM}_{2.5-10}\right)$ mode of the EUCAARI inventory was evaluated. A case study of the high polluted episode in April 2009 (Nordmann et al., 2014) was re-simulated for validating the influence of size segregation in EC transportation.

\section{Data and method}

The fully coupled "online" Weather Research and Forecasting/Chemistry model (WRF-Chem V3.5.1) is a state-of-theart regional air quality model (Grell et al., 2005). It is suitable for a broad spectrum of atmospheric research with horizontal extents ranging from hundreds of meters to thousands of kilometers. Trace gases, aerosols, and interactive processes with meteorology are simulated with several treatments in the model (Grell et al., 2005). The following is a brief summary of the primary WRF-Chem modules relevant to the current study.

In this study, the Carbon-Bond Mechanism version $\mathrm{Z}$ (CBMZ, Zaveri and Peters, 1999; Fast et al., 2006) was used for gas-phase atmospheric chemistry. 67 prognostic species and 164 reactions are included in CBMZ mechanism with a lumped structure approach, which classifies organic compounds according to their internal bond types. Fast-J scheme (Wild et al., 2000; Barnard et al., 2004) was used for calculating the rates for photolytic reactions within CBMZ.

The sectional approach MOdel for Simulating Aerosol Interactions and Chemistry (MOSAIC; Zaveri et al., 2008) was 
Table 1. Sectional approach for aerosols: particle dry-diameter ranges used in this study.

\begin{tabular}{lrrrrrrrr}
\hline & Bin 01 & Bin 02 & Bin 03 & Bin 04 & Bin 05 & Bin 06 & Bin 07 & Bin 08 \\
\hline Minimum diameter $(\mu \mathrm{m})$ & 0.0390625 & 0.078125 & 0.15625 & 0.3125 & 0.625 & 1.25 & 2.5 & 5.0 \\
Maximum diameter $(\mu \mathrm{m})$ & 0.078125 & 0.15625 & 0.3125 & 0.625 & 1.25 & 2.5 & 5.0 & 10.0 \\
\hline
\end{tabular}

applied to better represent the size segregated aerosol properties. In MOSAIC, dry aerosol particles with eight discrete size bins were selected with upper and lower bin diameters defined as shown in Table 1; and particles are assumed to be inter-mixed in each bin (Zaveri et al., 2008). MOSAIC treats the following chemical species: sulfate, methane sulfonate, nitrate, chloride, carbonate, ammonium, sodium, calcium, elemental carbon (EC), organic carbon (OC) and other inorganic mass. Both particle mass and particle number are simulated for each bin. Water uptake or loss will not transfer particles between bins, since bins are based on dry particle diameters (Zaveri et al., 2008). However, particle growth or reduction due to chemical processes (e.g., uptake or release of trace gases, etc.) and physical processes (e.g., coagulation, etc.) will transfer particles between bins (Chapman et al., 2009). In addition, particle coagulation and nucleation processes of sulfuric acid and water vapor are included (Fast et al., 2006; Zaveri et al., 2008). But the formation mechanism of Secondary Organic Aerosol (SOA) is not included in this version (Zaveri et al., 2008).

In WRF-Chem, dry (Binkowski and Shankar, 1995) and wet (Easter et al., 2004) deposition processes of aerosol particles are considered. The dry deposition of aerosol in the lowest model layer is derived from the deposition velocities, which is dependant on the sublayer resistance, aerodynamic resistance and surface resistance (Grell et al., 2005). The scavenging of cloud-phase and below-cloud aerosol by interception and impaction processes is calculated by lookup tables. It is worth mentioning that the particles are treated internally mixed in each bin; therefore the hygroscopicity of EC contained particles tends to be slightly overestimated in the model. Furthermore, the model tends to overestimate the removal rate of EC, especially for the wet deposition processes (Nordmann et al., 2014). In addition, Saide et al. (2012) pointed out that the irreversible removal of aerosol by rain in WRF-Chem might overestimate the wet deposition. However, it was mostly dominated by dry conditions before 16 September 2013 in this simulation.

As shown in Fig. 1, the simulation consists of four nested domains with 39 vertical layers. The spatial resolutions of domains (D01-D04) are 54, 18, 6, and $2 \mathrm{~km}$ respectively. The outer domain (D01) covers Europe and the inner domain (D04) focuses on Saxony in Germany, centered at Melpitz $\left(12.93^{\circ} \mathrm{E}, 51.53^{\circ} \mathrm{N}\right)$. The time period from 10 to 20 September 2013 was simulated, with 2 days spin-up. The model meteorology fields were driven and forced by Final Analysis (FNL) Operational Global Analysis data (http:

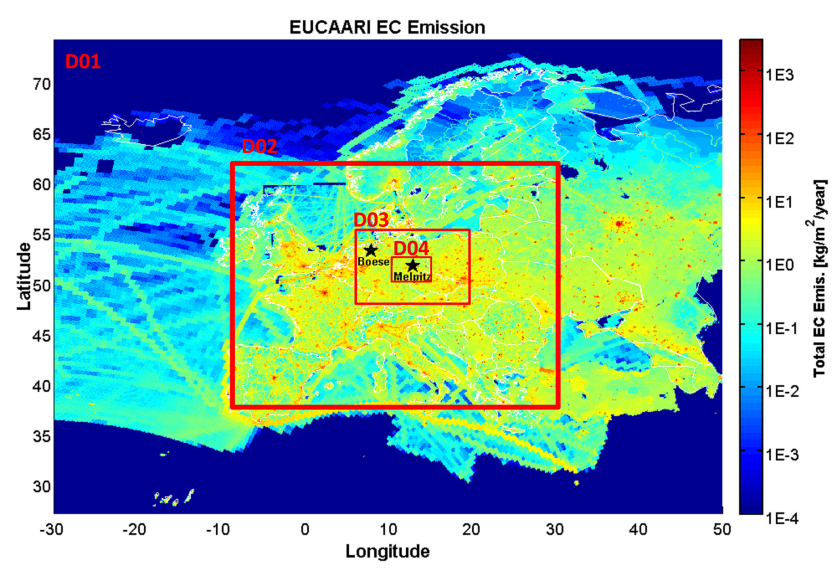

Figure 1. EUCARRI (resolution $7 \mathrm{~km}$ ) EC emission $\left(\mathrm{kg} \mathrm{m}^{-2}\right.$ year $\left.^{-1}\right)$. The 4 nested model domains (D01-D04) are indicated in the picture. Melpitz and Bösel (Boesel) are marked by black stars.

//rda.ucar.edu/datasets/ds083.2/) and sea surface temperature (SST) data set (http://polar.ncep.noaa.gov/sst/oper/Welcome. html) from NCEP (National Center for Environmental Prediction), with $1^{\circ}$ spatial and $6 \mathrm{~h}$ temporal resolution. The chemical initial and boundary conditions were driven and forced by MOZART-4 global model results (http://www. acd.ucar.edu/wrf-chem/mozart.shtml) with $1.9^{\circ} \times 2.5^{\circ}$ spatial and $6 \mathrm{~h}$ temporal resolution. The physical and chemical schemes used for the simulation are summarized in Table 2. The aerosol-cloud-radiation interaction is turned on.

\subsection{Emissions}

The anthropogenic emissions were taken from the PanEuropean Carbonaceous aerosol inventory (Visschedijk and Denier van der Gon, 2008) for EC and OC, which was developed in the framework of the European Integrated project on Aerosol Cloud Climate and Air Quality interactions (EUCAARI, Kulmala et al., 2011) for the year 2005. It is available on a spatial resolution of $1 / 8^{\circ} \times 1 / 16^{\circ}$ longitudelatitude grid, corresponding to around $7 \mathrm{~km}$ (Fig. 1). The EC emissions in different size modes $\left(\mathrm{PM}_{1}, \mathrm{PM}_{1-2.5}\right.$ and $\mathrm{PM}_{2.5-10}$ ) are provided; more details about the emissions in each mode and the gridding method were given in Denier van der Gon et al. (2010). The emissions are assumed to be equally distributed over the whole year in this study. A diurnal cycle of the emissions was applied with two maxima, around 07:00 and 18:00 local time. The emissions were al- 
located in the first six layers (from surface to about 550 meters) of the model depending on the emission types, such as area emission, small and large point sources. Nordmann et al. (2014) reported that the EC emissions of EUCAARI inventory are around $30 \%$ higher than the Lamarque inventory (Bond et al., 2007; Junker and Liousse, 2008; Lamarque et al., 2010) in Eastern European countries (Poland, Czech Republic and Belarus).

The EMEP inventory for 2013 (http://www.ceip.at, Mareckova et al., 2013), with $0.5^{\circ} \times 0.5^{\circ}$ spatial resolution, was applied in the model for the other anthropogenic emissions, such as $\mathrm{PM}, \mathrm{SO}_{2}, \mathrm{NO}_{x}, \mathrm{CO}, \mathrm{NH}_{3}, \mathrm{NH}_{4}$ and volatile organic compounds (VOC). The emissions of VOCs from EMEP were allocated to compounds used in CBMZ chemical mechanism of WRF-Chem.

In this study, biogenic emissions are taken from the Model of Emissions of Gases and Aerosols from Nature (MEGAN, Guenther et al., 2006). The Fire INventory from NCAR (FINN, Wiedinmyer et al., 2011), with $1 \mathrm{~km}$ spatial and 1 hour temporal resolution, was used in this study. The previous studies reported that the dust emission scheme (Saide et al., 2012) and the sea-salt emission scheme (Saide et al., 2012; Zhang et al., 2013) in WRF-Chem have large uncertainties. However, based on the filter measurements with high volume sampler DIGITEL DHA-80 (Walter Riemer Messtechnik, Germany) at Melpitz, dust and sea-salt contributed less than $3 \%$ of aerosol mass in the simulation period. Therefore, the online sea-salt and dust emissions were switched off.

\subsection{Observations}

The experimental data used in this paper were drawn from two major sources: first, the HOPE-Melpitz Campaign of the $\mathrm{HD}(\mathrm{CP})^{2}$ Observational Prototype Experiment (http://hdcp2. zmaw.de) and second, the German Ultrafine Aerosol Network (GUAN) (Birmili et al., 2009, 2015). The meteorological variables (e.g. temperature, relative humidity, wind speed, wind direction), gaseous pollutants (e.g. $\mathrm{O}_{3}, \mathrm{NO}_{x}, \mathrm{SO}_{2}$ ) were simultaneously measured. In addition, the radio-sounding data for the stations all-over Europe (http://www.weather. uwyo.edu/upperair/sounding.html) were used for evaluating the modeled atmosphere vertical structure.

The regional background site Melpitz $\left(12.93^{\circ} \mathrm{E}, 51.53^{\circ} \mathrm{N}\right)$ is representative for a larger rural area in Saxony Germany, detailed description was given in (Brüggemann and Spindler, 1999; Spindler et al., 2010, 2012; Poulain et al., 2011). A Twin Differential Mobility Particle Sizer (TDMPS, TROPOS, Leipzig, Germany; Birmili et al., 1999) was used to measure the Particle Number Size Distribution (PNSD) with an electrical mobility diameter between 5 and $800 \mathrm{~nm}$. An Aerodynamic Particle Sizer (APS Model 3320, TSI, Inc., Shoreview, MN USA) was employed to measure the PNSD with aerodynamic diameter from 0.5 to $10 \mu \mathrm{m}$. All of them were operated under dry conditions. All the particles were
Table 2. Configurations of WRF-Chem.

\begin{tabular}{ll}
\hline Physics & WRF option \\
\hline Micro physics & Lin et al. (1983) scheme \\
Surface & Rapid Update Cycle (RUC) land surface model \\
Boundary layer & YSU (Hong et al., 2006) \\
Cumulus & Grell 3D \\
Urban & 3-category UCM \\
Shortwave radiation & Goddard shortwave (Chou et al., 1998) \\
Longwave radiation & New Goddard scheme \\
Chemistry and Aerosol & Chem option \\
Gas-phase mechanism & CBMZ \\
Aerosol module & MOSAIC with 8 bins \\
Photolytic rate & Fast-J photolysis scheme \\
\hline
\end{tabular}

assumed as spherical (shape factor $=1$ ), with a density of $1.8 \mathrm{~g} \mathrm{~cm}^{-3}$ for the sub-micrometer particles and $1.5 \mathrm{~g} \mathrm{~cm}^{-3}$ for the super-micrometer particles (Heintzenberg et al., 1998). The mobility diameter can be calculated from the aerodynamic diameter and Particle Mass Size Distribution (PMSD) can be calculated from PNSD, as in Heintzenberg et al. (1998). Then PNSD and PMSD in the diameter range of $5-10000 \mathrm{~nm}$ can be derived from TDMPS $(5-638 \mathrm{~nm})$ and APS $(638-10000 \mathrm{~nm})$ measurements. A high-volume sampler DIGITEL DHA-80 (Walter Riemer Messtechnik, Germany), with sampling flux of about $30 \mathrm{~m}^{3} \mathrm{~h}^{-1}$, was used for parallel continuous daily samples of $\mathrm{PM}_{10}$, detailed information was given in Spindler et al. (2013). Additional radiosounding measurements were performed in Melpitz on the days 11-14, 17 and 19 September 2013.

At Melpitz, Bösel $\left(7.94^{\circ} \mathrm{E}, 53.0^{\circ} \mathrm{N}\right)$ and LeipzigTROPOS $\left(12.43^{\circ}\right.$ E $\left.51.35^{\circ} \mathrm{N}\right)$, Multi-angle Absorption Photometers (MAAP Model 5012, Thermo, Inc., Waltham, MA USA) were employed to determine the particle light absorption coefficient for dry particles (Birmili et al., 2015). All these stations are defined as rural or urban background station. The MAAPs were measured with $10 \mu \mathrm{m}$ cut-off inlet and the corrected mass absorption cross-section (MAC) of $5 \mathrm{~m}^{2} \mathrm{~g}^{-1}$ was used to derive the BC mass concentration for Melpitz (Genberg et al., 2013), and the manual suggested MAC of $6.6 \mathrm{~m}^{2} \mathrm{~g}^{-1}$ was used for Bösel and LeipzigTROPOS. Since EC and absorption-related BC were highly correlated in GUAN observation sites (Nordmann et al., 2013), we used the MAAP measured BC as the best approximation of EC (Nordmann et al., 2014) in this study.

\section{Result and discussion}

\subsection{Meteorology conditions}

The WRF performance on simulating the meteorological fields was evaluated with the Melpitz ground measurements data and radio-sounding measurements over the whole of Europe. The wind pattern in the simulated time period was dominated by westerly winds in Melpitz (Fig. 2d). It was mostly 

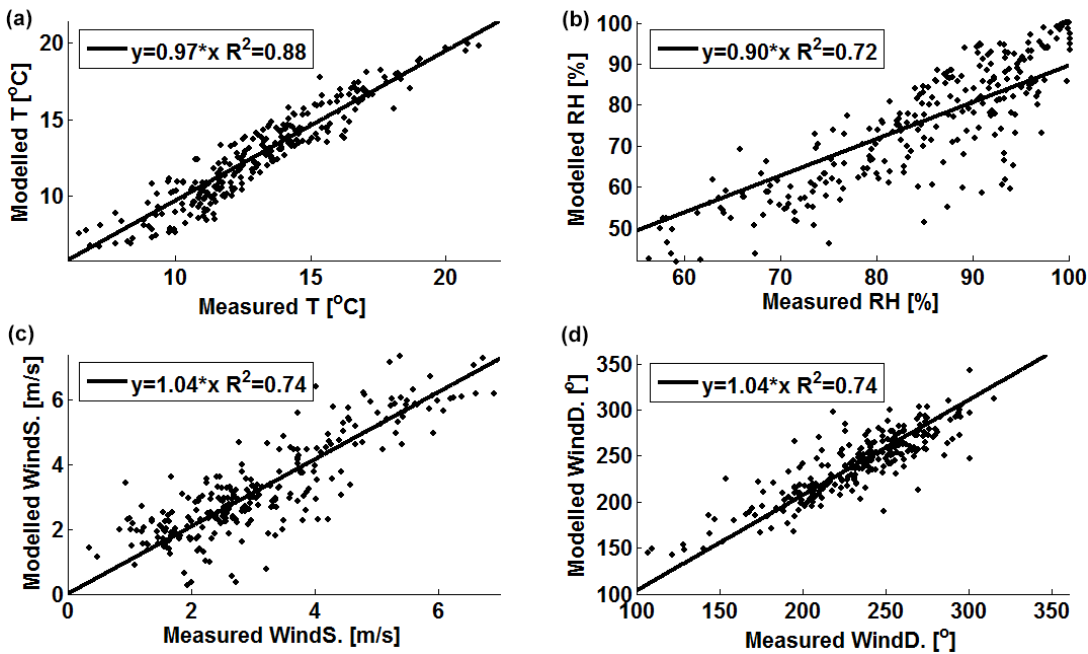

Figure 2. Comparison of meteorological variables between Melpitz ground-based measurements and WRF-Chem D04 result. (a) Temperature; (b) relative humidity; (c) wind speed; (d) wind direction.

dominated by dry conditions between 13 and 15 September in Melpitz. The air mass of northern Germany changed from continental to maritime after 15 September. The maritime air mass from the North Sea was relatively clean, with less anthropogenic pollutants. In 15-16 September, the concentration of primary gaseous pollutant $\mathrm{NO}$ was significantly lower at Melpitz than 13-14 September (Fig. S1 in the Supplement), and also the $\mathrm{PM}_{10}, \mathrm{PM}_{2.5}$ and $\mathrm{PM}_{1}$ mass concentrations were reduced by more than $50 \%$.

As shown in Fig. 2, the variances of temperature, relative humidity, wind speed and wind direction were validated with the ground measurements, with a correlation coefficient $\left(R^{2}\right)$ of $0.88,0.72,0.74$, and 0.74 respectively. The peaks in NO concentration can be reproduced by the model, although overestimated in the peaks (Fig. S1). The transport process and emission location were also supposed to be well described in the model, because NO has a very short lifetime and therefore a good indicator of nearby sources. These results show that the WRF model can well reproduce the near surface meteorological condition and transport processes at Melpitz.

The vertical gradient of the potential temperature is an important indicator for the stability of atmosphere. Figure S2 shows a $R^{2}$ map of comparison between radio-sounding observed and simulated vertical potential temperature in planetary boundary layer (PBL, under $3 \mathrm{~km}$ ). The $R^{2}$ values were higher than 0.8 for all the stations over Europe, especially for Melpitz region the $R^{2}$ was higher than 0.9. The comparison at the Melpitz site is shown in Table 3, together with some profile examples in Fig. S3. The meteorological vertical structure was well captured by the model, with $R^{2}$ value of $0.98,0.84,0.93$ and 0.70 for the potential temperature, water vapor mixing ratio, wind speed and wind direction respectively. The results indicate that WRF well simulated the
Table 3. Comparison result for meteorological variables between Melpitz radio-sounding measurements and WRF-Chem model.

\begin{tabular}{lrrr}
\hline & Slope & $R^{2}$ & $\begin{array}{r}\text { Data point } \\
\text { Number }\end{array}$ \\
\hline Potential temperature & 0.99 & 0.98 & 586 \\
Water vapor mixing ratio & 0.81 & 0.84 & 586 \\
Wind speed & 0.90 & 0.93 & 586 \\
Wind direction & 1.02 & 0.70 & 586 \\
\hline
\end{tabular}

meteorological vertical structure and wind pattern, especially in central Europe (Melpitz region with $2 \mathrm{~km}$ resolution).

\subsection{Particle size distribution}

The modeled particle number size distribution (PNSD) and particle mass size distribution (PMSD) for Melpitz were compared with the measurements, shown in Fig. 3. For the fine mode $\left(\mathrm{PM}_{1}\right.$, or sub-micron particles) aerosol the agreement is acceptable, but the model significantly overestimated the coarse mode $\left(\mathrm{PM}_{2.5-10}\right)$ mass/number. The meteorology condition was well reproduced by the model. The transportation process was also supposed to be well simulated. It indicates that there may be some unrealistic sources of particles larger than $2.5 \mu \mathrm{m}$ included in the model, which leads to the overestimation of coarse mode. The detailed discussion about the unrealistic sources will be given in Sect. 3.3.

We found out that EC had a very high contribution of modeled coarse mode aerosol mass when the EC plumes hit Melpitz (Figs. 4a and 5a). In order to investigate the reasons of the EC plumes and its influence on coarse mode overestimation, a more detailed case study for the plume episode in the morning of 13 September will be given in Sect. 3.3. 

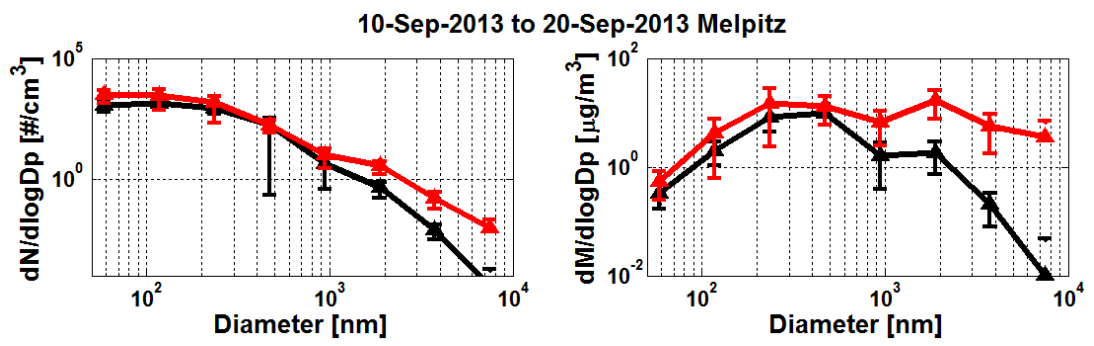

Figure 3. Comparison of Particle Number Size Distribution (PNSD, left) and Particle Mass Size Distribution (PMSD, right) between WRFChem model and Melpitz measurements. Model results indicated by the red lines and measurements by the black lines. The size distributions are averaged in the period 10-20 September 2013, the error bar indicates the upper and lower limits.

\subsection{Elemental carbon point source size segregation and evaluation}

In order to evaluate the EC emission in central Europe and investigate local effect of point source, MAAP measurements of three background sites (Melpitz, Leipzig-TROPOS and Bösel) were compared with modeled results (Fig. 4). In Leipzig-TROPOS, the relatively high EC concentration in the morning and night but low concentration at the noontime could have resulted from the development of planet boundary layer and traffic rush hours. According to modeled transportations, Melpitz and Bösel were influenced by the point source plume, but Leipzig-TROPOS was not (see Figs. 5b and S4). Here we use MAAP instead of DIGITEL measurement to compare with the model output, because only MAAP data are available for all those three sites and the higher temporal resolution of the MAAP is better for investigating the point source plume influence.

The model substantially overestimated the EC concentration in Melpitz especially for high episode peaks (Fig. 4a), during which the modeled EC concentration in $\mathrm{PM}_{10}$ can reach up to about 3-4 times higher than that in $\mathrm{PM}_{2.5}$. While outside the peaks, EC concentration in $\mathrm{PM}_{10}$ and $\mathrm{PM}_{2.5}$ were very close to each other. Comparing with MAAP measurement, $\mathrm{EC}$ in $\mathrm{PM}_{10}$ was on average overestimated by a factor of 2.8 at Melpitz, and by a factor up to 610 for the peak periods. This overestimation of EC was due to the plume from a point source emission of type SNAP-5 (extraction and distribution fossil fuels, nomenclature described in Visschedijk and Denier van der Gon, 2008; Pouliot et al., 2012) located between Leipzig and Melpitz. Figure 5 is an example snapshot showing the EC plume passing through Melpitz at 05:00 a.m. on 13 September 2013. Plumes from the same sources also similarly influenced other peak periods to a different extent. When the plume hit Melpitz, the overestimation of EC concentration was substantial even when the uncertainties in the modeled transportation within $12 \times 12 \mathrm{~km}^{2}$ was accounted for (shaded area in Fig. 4a), and EC contributed $30-67 \%$ of coarse mode aerosol mass. At the same time, Leipzig was not influenced by point source plume, because of the pre- vailing westerly wind in domain D04 (Fig. 5b). The comparison at the Leipzig-TROPOS site was thus much better (Fig. 4b). There, EC was only slightly overestimated by less than $40 \%$, which may be due to the seasonal variability and/or decreasing emissions ( $\sim 25 \%$ from 2010 to 2013, based on long-term MAAP measurements in LeipzigTROPOS and DIGITEL measurements in Melpitz) in the context of "low emission zones" (http://gis.uba.de/website/ umweltzonen/umweltzonen_en.php) implemented in several cities of the region (Leipzig and Halle/Saale) and the rest of Germany (Cyrys et al., 2014). The different behaviors of model at these two sites indicate that the coarse mode EC emission in the point sources near Melpitz can be significantly overestimated.

This EC plume effect was not only found in Melpitz. As shown in Fig. S4, Bösel was also influenced by a nearby EC point source in the morning of 13 and 14 September 2013 (also Fig. 4c). The EC concentration was overestimated and had a high coarse mode fraction, similar to Melpitz. However, the overestimation of EC was not as significant as for Melpitz, with $\sim 87 \%$ on average and about $200-400 \%$ during the peak periods. The fraction of EC in coarse mode was also not as high as in Melpitz. One reason could be the lower intensity of the point source nearby Bösel than the one near Melpitz (Fig. S4). Another reason may be the artificial dilution of local emissions by the coarser modelling resolution (Genberg et al., 2013), because we only have the highest resolution of $2 \mathrm{~km}$ covering the regions around Melpitz (D04), but $6 \mathrm{~km}$ resolution for Bösel (D03).

These results imply that the EC point sources in Germany can be overestimated by a factor of 2-10 in the EUCAARI emission inventory, especially for the coarse mode EC emission in the large point sources. To further evaluate the coarse mode EC emission (ECc, EC in $\mathrm{PM}_{2.5-10}$ ) over the whole of Europe, we first checked the emission fraction of ECc to the total EC in EUCAARI inventory. As shown in Fig. 6a, this fraction is generally lower than $10 \%$ over large regions in Western Europe. For almost all of the point sources, the ECc emission fractions are higher than $30 \%$ (Fig. 6b), within which there are 3 and 10 point sources surrounding the Melpiz and Bösel regions, respectively, with ECc emis- 

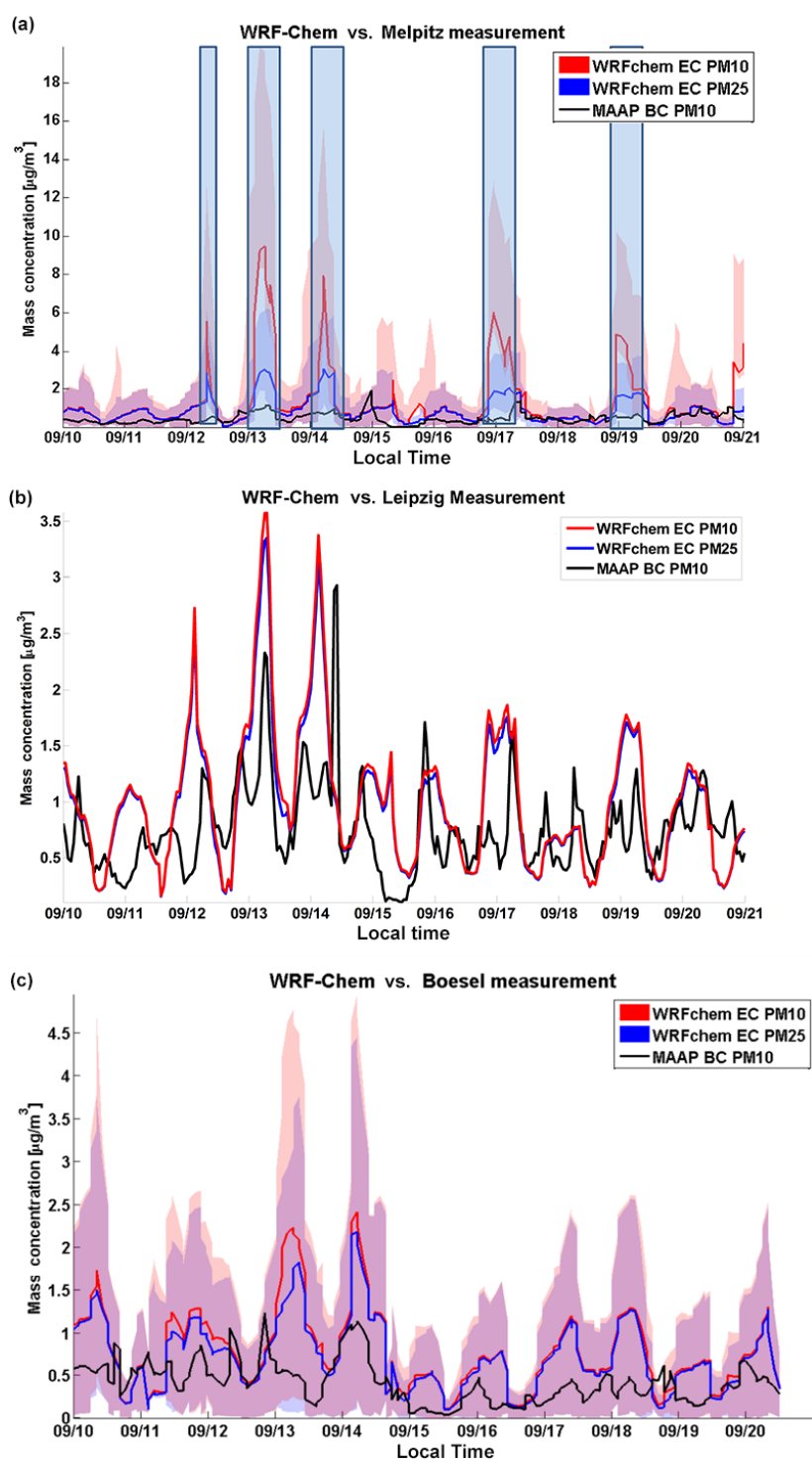

Figure 4. The comparison of EC/BC concentration between model and MAAP measurements. Red line: EC concentration in $\mathrm{PM}_{10}$ of model result; blue line: EC concentration in $\mathrm{PM}_{2.5}$ of model result; black line: $\mathrm{BC}$ concentration in $\mathrm{PM}_{10}$ of MAAP measurement, used as the best approximation of EC. The shaded areas indicate the model uncertainty defined by the maxima (upper limit of the shade) and minima (lower limit of the shade) values within $12 \mathrm{~km}$ distance from Melpitz/Bösel. The blue rectangles mark the EC plume episodes at Melpitz. (a) Melpitz: modelling result derived from D04 simulation with $2 \mathrm{~km}$ resolution; (b) Leipzig-TROPOS: modelling result derived from D04 simulation with $2 \mathrm{~km}$ resolution; (c) Bösel: modelling result derived from D03 simulation with $6 \mathrm{~km}$ resolution.

sion fractions even higher than $80 \%$ (Table S1 and Fig. 6b). It is worth mentioning that these point sources with high ECc emission fractions also have a very high total EC emission rate. For example, the point source, influencing Melpitz in the morning of 13 September, is the largest point source for
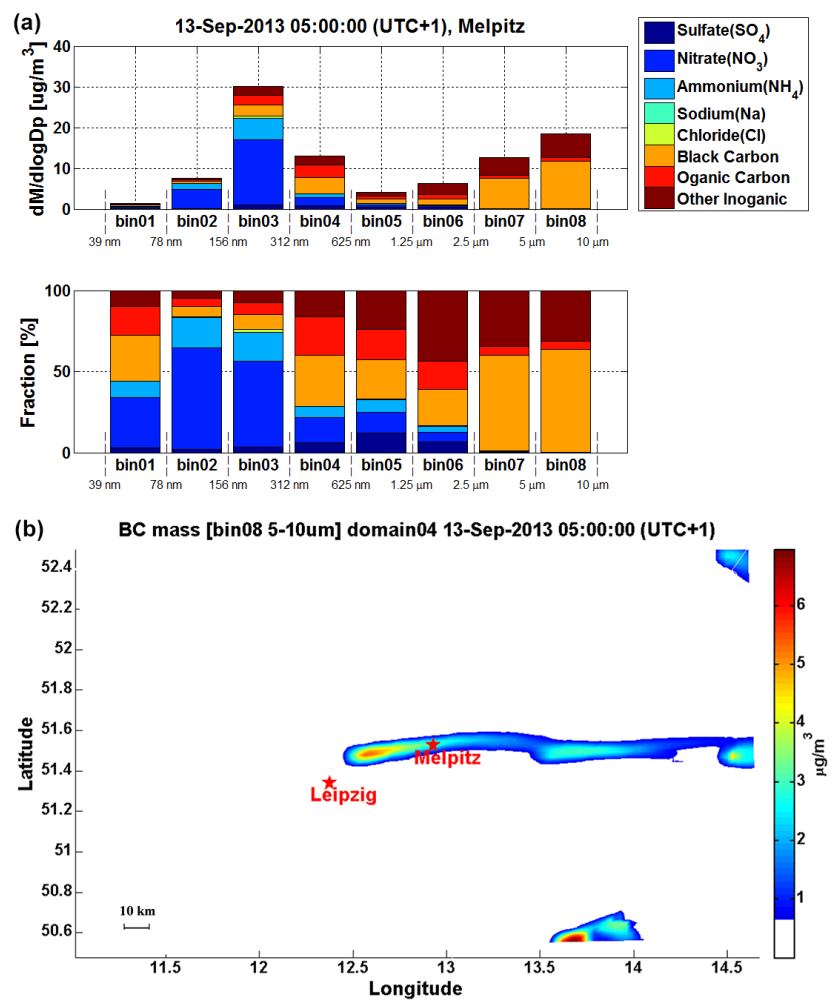

Figure 5. The model result: (a) aerosol chemistry compounds for each bins of Melpitz; (b) horizontal distribution of EC in bin08 [5$10 \mu \mathrm{m}]$ at 05:00 (UTC +1$)$ of 13 September 2013.

SNAP-5 in Germany with a share of about $20 \%$ in the total EC point emission. EC emissions from the SNAP-5 point sources originate from coal-mining, storage and handling (Visschedijk and Denier van der Gon, 2008; Pouliot et al., 2012; Denier van der Gon et al., 2015), for which a relatively high fraction in coarse mode emission is expected. Therefore, the emission fraction of ECc may be true. But, the total $\mathrm{EC}$ emission rate might be too high due to the overestimation of EC scaling factor out of all emitted compounds. But it is hard to quantify it due to the fact that few data are available for the storage and handling of coal, and about chemical composition and size distribution of the emission in SNAP-5 type of emissions.

Note that the dry and wet deposition processes also contribute to the uncertainty of the modeling results. The dominant removal process for EC is wet deposition (Genberg et al., 2013); Croft et al. (2005) estimated that about $75 \%$ of the EC is removed by wet deposition and $25 \%$ by dry deposition, based on global model runs. And the wet deposition of EC may be overestimated in the WRF-Chem model due to the irreversible removal process (Yang et al., 2011; Saide et al., 2012) and the internal mixture of EC (Nordmann et al., 2014). It indicates that the overestimation of EC should result from the emission source instead of the deposition process, although the uncertainty of deposition would influence the 

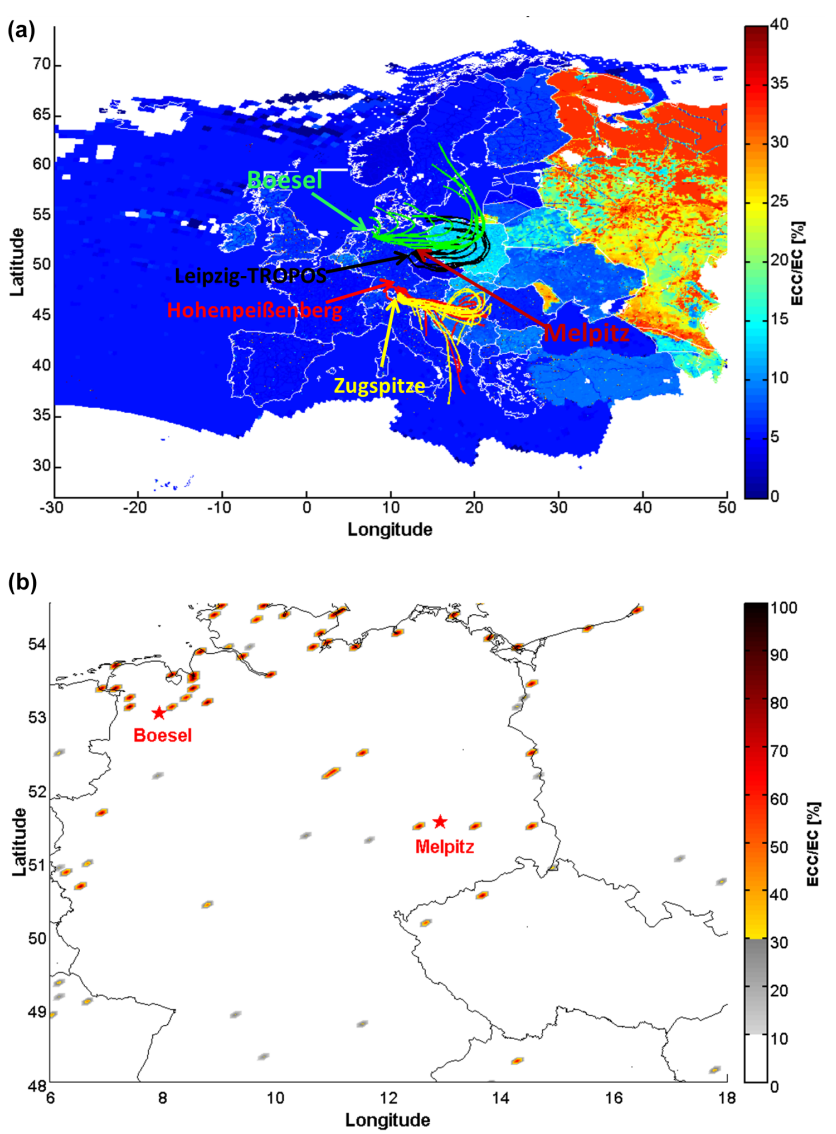

Figure 6. EUCAARI EC emission coarse mode fraction (ECc). (a) ECc result of total emission, including area and point sources. The location of Bösel, Leipzig-TROPOS, Melpitz, Hohenpeißenberg and Zugspitze are marked on the map. The colored lines indicated the 3-day back trajectories for each site (without Melpitz), in the period from 1 April 2009 to 4 April 2009 with $6 \mathrm{~h}$ interval. (b) ECc result of point source emissions.

emission evaluation results. More measurements and modeling studies are still needed for the quantified evaluation of the deposition processes uncertainty.

\subsection{Influence on elemental carbon transportation}

EC is in general mostly emitted in the fine mode, especially for the area emissions (Echalar et al., 1998; Hitzenberger and Tohno, 2001; Kuenen et al., 2014), although the SNAP-5 point sources may be an exception. The major SNAP-5 point sources giving coarse EC are coal mines and originate from storage and handling - dust being released due to loading and unloading, driving on the premises etc. Based on the EUCAARI inventory, the average ECc emission fraction for Western Europe is around 5\%, also about $5 \%$ in Germany of year 2009 TNO-MACC_II inventory (Kuenen et al., 2014). This is consistent with previous knowledge. But on the contrast to the generally low ECc emission fraction, this fraction is relatively high in Eastern Europe (e.g. Poland, Slovakia and Belarus), about $15-20 \%$, and about $35 \%$ in Poland of TNO-MACC_II inventory (Kuenen et. al., 2014). For Russia (including Kaliningrad in the north of Poland) and Moldova the fraction can reach up to $20-40 \%$, and about $17 \%$ in Russia of TNO-MACC_II inventory (Kuenen et al., 2014). As shown in the long-term (2003-2011) filter measurement study at Melpitz (Spindler et al., 2013), in the eastern wind dominated period when the air mass came from Eastern Europe and Russia, the EC coarse mode mass fraction was only in the range of $4-15 \%(\sim 10 \%$ in average). Assuming that EC particles would not change the size during transportation, EUCAARI inventory may overestimate the fraction of ECc by about $5-10 \%$ for Eastern Europe and 10-30 \% for Russia.

The life-time for fine mode particles is about 5-7 days, but only 1-2 days for the coarse mode aerosol (Jaenicke, 1980; Petzold and Kärcher, 2012; Croft et al., 2014). Therefore, the fine mode EC particles have more time to accumulate in the atmosphere. To evaluate the influence of this high coarse mode EC emission fraction in Eastern Europe on EC's longrange transportation, we constructed the following concept model. In a steady state, where sources are continuous and there is a quasi-equilibrium between sources and sinks such that the EC concentration is constant in time. For the same emission rate of EC, the equilibrium mass concentration of fine mode will be 2-3 times higher than coarse mode as described in Eq. (1) (Croft et al., 2014).

$\frac{\mathrm{d} C(t)}{\mathrm{d} t}=S(t)-\frac{C(t)}{\tau(t)}$,

where $C(t)$ is the EC concentration at time $t, S(t)$ is the source rate, and $\tau(t)$ is the removal timescale. In the steady state, a quasi-equilibrium between sources and sinks, $\tau(t)$ is defined as lifetime (Croft et al., 2014). Then the deposition rate (sink rate), with unit of percentage per second, is proportional to $1 / \tau(t)$ for stationary concentrations. The deposition rate of EC in coarse mode is 2-3 times higher than in fine mode.

On the other hand, longer lifetime makes fine mode EC particles have more opportunity to be transported from Eastern Europe to Melpitz. In the following scenario, the particles were emitted instantly into the air mass, which was assumed to be transported by an eastern wind pattern with $5 \mathrm{~m} \mathrm{~s}^{-1}$ speed. It will take about 4-5 days from Moskva to Melpitz, and 1-2 days from Warsaw, Poland. During the transport, only the deposition process was active, without subsequent emission. About $30-55$ and $65-85 \%$ of fine mode EC can be transported to Melpitz from Moskva and Warsaw, Poland respectively, but just 5-20 and 10-60\% for the coarse mode EC can make the same way (Fig. 7).

The overestimation of ECc emission fraction in EUCAARI inventory resulted in less EC transported from the Eastern Europe and Russia to Melpitz. This may be one reason for the underestimation of the EC mass concentration in the other studies under eastern wind pattern. For instance, Genberg et al. (2013) and Nordmann et al. (2014) reported 
Table 4. Comparison between the adjusted EC coarse emission simulation and original one.

\begin{tabular}{|c|c|c|c|c|c|c|c|}
\hline \multirow[t]{2}{*}{ Sites } & \multicolumn{3}{|c|}{$\begin{array}{l}\text { Adjusted EC } \\
\text { coarse fraction }\end{array}$} & \multicolumn{3}{|c|}{$\begin{array}{c}\text { Original } \\
\text { (Nordmann et al., 2014) }\end{array}$} & \multirow[t]{2}{*}{ Air mass } \\
\hline & MB & MNB & $R^{2}$ & MB & MNB & $R^{2}$ & \\
\hline Bösel & 0.12 & 0.13 & 0.81 & -0.31 & -0.21 & 0.61 & East \\
\hline Leipzig-TROPOS & -1.01 & -0.47 & 0.69 & -1.57 & -0.7 & 0.35 & East \\
\hline Hohenpeißenberg & -0.52 & -0.64 & 0.43 & -0.59 & -0.72 & 0.66 & Southeast \\
\hline Zugspitze & -0.22 & -0.56 & 0.72 & -0.26 & -0.46 & 0.79 & Southeast \\
\hline
\end{tabular}

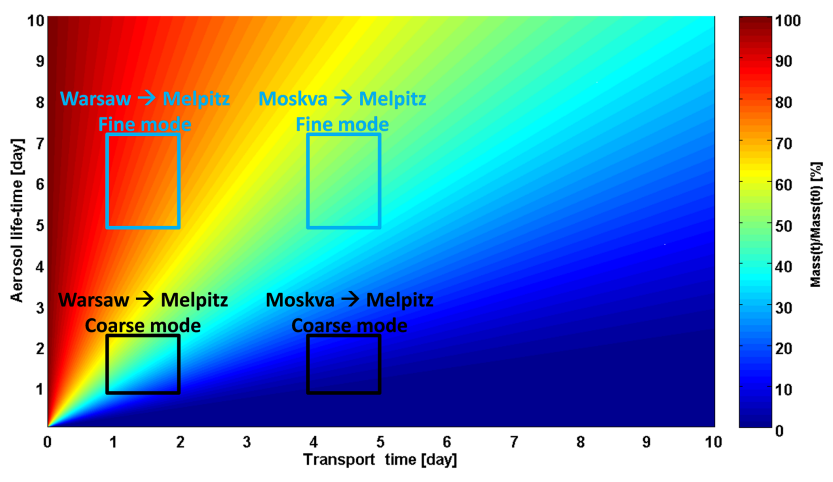

Figure 7. Aerosol mass residential rate with relationship of transport time and lifetime. The color indicates the percentage of aerosol mass that can be transported to Melpitz.

an underestimation of EC in Europe with the simulation of EUCAARI inventory.

Nordmann et al. (2014) reported an underestimation about $50 \%$ of EC mass concentration in Germany during MarchApril 2009, especially for the period when air mass approached the observation sites from eastern directions. And they suspected that the EC emission in Eastern Europe may be underestimated by a factor of 2 to 5 . In order to investigate the possible influence of the overestimated ECc emission fraction in Eastern Europe in this case, we re-simulated the same time period as in Nordmann et al. (2014) with the adjusted EC emission inventory. The ECc emission fraction was adjusted to $5 \%$ (the average value for Western Europe, longitude $<15^{\circ} \mathrm{E}$ ) if it is higher than $5 \%$ in Eastern Europe (longitude $>15^{\circ} \mathrm{E}$ ). The new simulation and the results of Nordmann et al. (2014) are shown in Table 4. The air mass back trajectories of the high EC concentration period ( 1 to 4 April 2009, Nordmann et al., 2014) are shown in Fig. 6a. The back trajectories were calculated based on the GDAS (with $0.5^{\circ}$ resolution) data set with the Hysplit model (http: //www.arl.noaa.gov/HYSPLIT_info.php). The underestimation for EC was significantly improved at Bösel and LeipzigTROPOS. For Bösel, the mean normalized bias (MNB) increased from -21 to $13 \%$ and $R^{2}$ from 0.61 to 0.81 ; for Leipzig-TROPOS, the MNB increased from -70 to $-47 \%$ and $R^{2}$ from 0.35 to 0.69 . The results of Hohenpeißenberg and Zugspitze were not significantly changed, with less than $10 \%$ differences in MNB. This is because the air masses of Bösel and Leipzig-TROPOS originated from Eastern Europe passing through Poland, where the ECc emission fraction in EUCAARI inventory is high. But it was not the case for southeastern Europe, where the air masses of Hohenpeißenberg and Zugspitze originated from (Fig. 6a). Thus, it indicates that the Nordmann et al. (2014)'s conclusion of underestimation of EC emission in Eastern Europe for 2009 is generally correct, especially for southeastern Europe (e.g.: Austria, Slovenia, Croatia etc.). However, the overestimation of ECc emission fraction in Eastern Europe (e.g.: Poland, Belarus, Russia etc.) could be another reason for the underestimation of modeled EC mass concentration in the eastern wind pattern. It contributed about $20-40 \%$ underestimation of the EC mass concentration in Germany. This is consistent with the result of concept model, which showed the adjustment of ECc emission fraction in Warsaw Poland would make about 25-55\% difference of EC transported to Melpitz.

\section{Conclusions}

A WRF-Chem simulation was performed for the period between 10 and 20 September 2013, with an inner most domain of $2 \mathrm{~km}$ resolution for the Melpitz region in eastern Germany. The high-resolution EUCAARI inventory of EC emission was applied in the model. The measurements of HOPE-Melpitz Campaign and GUAN network project were used for modelling results validation.

The comparison of particle number/mass size distributions showed that the coarse mode particle concentration was substantially overestimated by the model. However, the meteorology and transport process were well simulated, because of the good agreement with the ground-based and radiosounding meteorological measurements. These results indicated that the overestimation of the coarse mode particle should mostly come from the uncertainty of emission inventories. The comparisons of EC mass concentrations at the Melpitz, Leipzig-TROPOS and Bösel sites indicated that the EC point sources may be overestimated by a factor of 2-10, which made a remarkable unrealistic plume in Melpitz. 
The coarse mode EC emission fraction was substantially overestimated in Eastern Europe (e.g.: Poland, Belarus etc.) and Russia by EUCAARI inventory, with about $10-30 \%$ for Russia and 5-10\% for the Eastern European countries. A concept model and a case study were designed to interpret the influence of this overestimation on EC long-range transportation. Due to the overestimation of ECc emission fraction, EC mass transported from Moskva to Melpitz would decrease by about $25-35 \%$ of ECc mass concentration, and decrease by about $25-55 \%$ from Warsaw to Melpitz. This is because the coarse mode particle has a shorter life-time and therefore less opportunity for being long-range transported and accumulated in the atmosphere. The March-April 2009 case (Nordmann et al., 2014) was re-simulated with adjusted ECc emission fraction in Eastern Europe in order to validate the influence on transportation. The result showed that the overestimation of ECc emission fraction in Eastern Europe was one reason of the underestimation of EC in Germany, when the air masses came from eastern direction. It contributed to an underestimation of about $20-40 \%$.

Will the health and climatic effects of atmospheric EC particles be local, regional or global? This is to some extent determined by the transportation of EC, which is largely influenced by its size distribution. The size segregation information of EC particles should be carefully considered in the model validation and climate change evaluation studies. Unfortunately, the size segregation information is not included in most of the current global EC emission inventories, and the size segregation in EUCAARI inventory only covers Europe and is still with high uncertainty. More EC particle size distribution measurements (e.g.: online analysis of SP2, offline analysis of Berner/MOUDI samples, etc.) and long-term model simulation studies are needed to further improve the EC emission inventories.

\section{The Supplement related to this article is available online at doi:10.5194/acp-16-1823-2016-supplement.}

Acknowledgements. Continuous aerosol measurements at Melpitz were supported by the German Federal Environment Ministry (BMU) grants F\&E 370343200 (German title: "Erfassung der Zahl feiner und ultrafeiner Partikel in der Außenluft") and F\&E 371143232 (German title: "Trendanalysen gesundheitsgefährdender Fein- und Ultrafeinstaubfraktionen unter Nutzung der im German Ultrafine Aerosol Network (GUAN) ermittelten Immissionsdaten durch Fortführung und Interpretation der Messreihen”. The black carbon data used for this paper can be accessed through the German Ultrafine Aerosol Network's data dissemination page: doi:10.5072/guan). The HOPE campaign was funded by the German Research Ministry under the project number 01LK1212 C. The work of Y. F. Cheng and H. Su was supported by the Max Planck Society (MPG) and National Natural Science Foundation of China (41330635). We would also like to thank Markus Hermann and Sascha Pfeifer for useful suggestions.
Edited by: V.-M. Kerminen

\section{References}

Barnard, J. C., Chapman, E. G., Fast, J. D., Schemlzer, J. R., Slusser, J. R., and Shetter, R. E.: An evaluation of the FAST-J Photolysis Algorithm for predicting nitrogen dioxide photolysis rates under clear and cloudy sky conditions, Atmos. Environ., 38, 3393 3403, 2004.

Binkowski, F. S. and Shankar, U.: The Regional Particulate Matter Model: 1. Model description and preliminary results, J. Geophys. Res., 100, 26191-26209, doi:10.1029/95JD02093, 1995.

Birmili, W., Stratmann, F., and Wiedensohler, A.: Design of a DMAbased size spectrometer for a large particle size range and stable operation, J. Aerosol Sci., 30, 549-533, 1999.

Birmili, W., Weinhold, K., Nordmann, S., Wiedensohler, A., Spindler, G., Müller K., Herrmann, H., Gnauk, T., Pitz, M., Cyrys, J., Flentje, H., Nickel, C., Kuhlbusch, T., Löschau G., Haase, D., Meinhardt, F., Schwerin, A., Ries, L., and Wirtz, K.: Atmospheric aerosol measurements in the German Ultrafine Aerosol Network (GUAN) - Part - soot and particle number size distributions, Gefahrst. Reinhalt. L., 69, 137-145, 2009.

Birmili, W., Weinhold, K., Merkel, M., Rasch, F., Sonntag, A., Wiedensohler, A., Bastian, S., Schladitz, A., Löschau, G., Cyrys, J., Pitz, M., Gu, J., Kusch, T., Flentje, H., Quass, U., Kaminski, H., Kuhlbusch, T. A. J., Meinhardt, F., Schwerin, A., Bath, O., Ries, L., Wirtz, K., and Fiebig, M.: Long-term observations of tropospheric particle number size distributions and equivalent black carbon mass concentrations in the German Ultrafine Aerosol Network (GUAN), Earth Syst. Sci. Data Discuss., 8, 935-993, doi:10.5194/essdd-8-935-2015, 2015.

Bond, T. C., Streets, D. G., Yarber, K. F., Nelson, S. M., Woo, J., and Klimont, Z.: A technologybased global inventory of black and organic carbon emissions from combustion, J. Geophys. Res., 109, D14203, doi:10.1029/2003JD003697, 2004.

Bond, T. C., Bhardwaj, E., Dong, R., Jogani, R., Jung, S., Roden, C., Streets, D. G., and Trautmann, N. M.: Historical emissions of black and organic carbon aerosol from energy-related combustion, 1850-2000, Global Biogeochem. Cy., 21, GB2018, doi:10.1029/2006GB002840, 2007.

Bond, T. C., Doherty, S. J., Fahey, D. W., Forster, P. M., Berntsen, T., DeAngelo, B. J., Flanner, M. G., Ghan, S., Kärcher, B., Koch, D., Kinne, S., Kondo, Y., Quinn, P. K., Sarofim, M. C., Schultz, M. G., Schulz, M., Venkataraman, C., Zhang, H., Zhang, S., Bellouin, N., Guttikunda, S. K., Hopke, P. K., Jacobson, M. Z., Kaiser, J. W., Klimont, Z., Lohmann, U., Schwarz, J. P., Shindell, D., Storelvmo, T., Warren, S. G., and Zender, C. S.: Bounding the role of black carbon in the climate system: a scientific assessment, J. Geophys. Res.-Atmos., 118, 5380-5552, doi:10.1002/jgrd.50171, 2013.

Brüggemann E. and Spindler, G.: Wet and dry deposition of sulphur at the site Melpitz in East Germany, Water Air Soil Poll., 109, 81-99, 1999.

Chapman, E. G., Gustafson Jr., W. I., Easter, R. C., Barnard, J. C., Ghan, S. J., Pekour, M. S., and Fast, J. D.: Coupling aerosolcloud-radiative processes in the WRF-Chem model: Investigat- 
ing the radiative impact of elevated point sources, Atmos. Chem. Phys., 9, 945-964, doi:10.5194/acp-9-945-2009, 2009.

Cheng, Y. F., Wiedensohler, A., Eichler, H., Su, H., Gnauk, T., Brüggemann, E., Herrmann, H., Heintzenberg, J., Slanina, J., Tuch, T., Hu, M., and Zhang, Y. H.: Aerosol optical properties and related chemical apportionment at Xinken in Pearl River Delta of China, Atmos. Environ., 42, 6351-6372, doi:10.1016/j.atmosenv.2008.02.034, 2008.

Cheng, Y. F., Berghof, M., Garland, R. M., Wiedensohler, A., Wehner, B., Müller, T., Su, H., Zhang, Y. H., Achtert, P., Nowak, A., Pöschl, U., Zhu, T., Hu, M., and Zeng, L. M.: Influence of soot mixing state on aerosol light absorption and single scattering albedo during air mass aging at a polluted regional site in northeastern China, J. Geophys. Res., 114, doi:10.1029/2008jd010883, 2009.

Chou, M., Suarez, M., Ho, C., Yan, M., and Lee, K.: Parameterizations for Cloud Overlapping and Shortwave Single-Scattering Properties for Use in General Circulation and Cloud Ensemble, Models, J. Climate, 11, 202-214, 1998.

Croft, B., Lohmann, U., and von Salzen, K.: Black carbon ageing in the Canadian Centre for Climate modelling and analysis atmospheric general circulation model, Atmos. Chem. Phys., 5, 19311949, doi:10.5194/acp-5-1931-2005, 2005.

Croft, B., Pierce, J. R., and Martin, R. V.: Interpreting aerosol lifetimes using the GEOS-Chem model and constraints from radionuclide measurements, Atmos. Chem. Phys., 14, 4313-4325, doi:10.5194/acp-14-4313-2014, 2014

Cyrys, J., Peters, A., Soentgen, J., and Wichmann, H. E.: Low emission zones reduce $\mathrm{PM}_{10}$ mass concentrations and diesel soot in German cities, J. Air Waste Manage. Assoc., 64, 481-487, 2014.

Denier van der Gon, H. A. C., Visschedijk, A., Van der Brugh, H., and Dröge, R.: A High Resolution European Emission Database for the Year 2005, a Contribution to the UBAproject PAREST: Particle Reduction Strategies, TNO report TNO-034-UT-201001895_RPTML, published by the German Federal Environment Agency (Umweltbundesamt) as Texte 41/2013, Utrecht, available at: https://www.umweltbundesamt.de/publikationen (last access: 3 September 2015), 2010.

Denier van der Gon, H. A. C., Bergström, R., Fountoukis, C., Johansson, C., Pandis, S. N., Simpson, D., and Visschedijk, A. J. H.: Particulate emissions from residential wood combustion in Europe - revised estimates and an evaluation, Atmos. Chem. Phys., 15, 6503-6519, doi:10.5194/acp-15-6503-2015, 2015.

Easter, R. C., Ghan, S. J., Zhang, Y., Saylor, R. D., Chapman, E. G., Laulainen, N. S., Abdul-Razzak, H., Leung, L. R., Bian, X., and Zaveri, R. A.: MIRAGE: model description and evaluation of aerosols and trace gases, J. Geophys. Res., 109, D20210, doi:10.1029/2004JD004571, 2004.

Echalar, F., Artaxo, P., Martins, J. V., Yamasoe, M., Gerab, F., Maenhaut, W., and Holben, B.: Long-term monitoring of atmospheric aerosols in the Amazon Basin: source identification and apportionment, J. Geophys. Res.-Atmos., 103, 31849-31864, 1998.

EEA (European Environment Agency): European Union Emission Inventory Report 1990-2011 Under the UNECE Convention on Long-range Transboundary Air Pollution (LRTAP), EEA Technical report No. 10/2013, Copenhagen, doi:10.2800/44480, 2013.

Fast, J. D., Gustafson Jr., W. I., Easter, R. C., Zaveri, R. A., Barnard, J. C., Chapman, E. G., Grell, G. A., and Peckham, S.
E.: Evolution of ozone, particulates, and aerosol direct radiative forcing in the vicinity of Houston using a fully coupled meteorology-chemistry-aerosol model, J. Geophys. Res., 111, D21305, doi:10.1029/2005JD006721, 2006.

Genberg, J., Denier van der Gon, H. A. C., Simpson, D., Swietlicki, E., Areskoug, H., Beddows, D., Ceburnis, D., Fiebig, M., Hansson, H. C., Harrison, R. M., Jennings, S. G., Saarikoski, S., Spindler, G., Visschedijk, A. J. H., Wiedensohler, A., Yttri, K. E., and Bergström, R.: Light-absorbing carbon in Europe - measurement and modelling, with a focus on residential wood combustion emissions, Atmos. Chem. Phys., 13, 87198738, doi:10.5194/acp-13-8719-2013, 2013.

Grell, G. A., Peckham, S. E., Schmitz, R., McKeen, S. A., Frost, G., Skamarock, W. C., and Eder, B.: Fully coupled "online" chemistry within the WRF model, Atmos. Environ., 39, 6957-6975, 2005.

Guenther, A., Karl, T., Harley, P., Wiedinmyer, C., Palmer, P. I., and Geron, C.: Estimates of global terrestrial isoprene emissions using MEGAN (Model of Emissions of Gases and Aerosols from Nature), Atmos. Chem. Phys., 6, 3181-3210, doi:10.5194/acp-63181-2006, 2006.

Hansen, J. E., Sato, M., Ruedy, R., Lacis, A., and Oinas, V.: Global warming in the twenty-first century: an alternative scenario, $\mathrm{P}$. Natl. Acad. Sci. USA, 97, 9875-9880, 2000.

Heintzenberg, J., Müller, K., Birmili, W., Spindler, G., and Wiedensohler, A.: Mass-related aerosol properties over the Leipzig Basin, J. Geophys. Res.-Atmos., 103, 13125-13135, 1998.

Hitzenberger, R. and Tohno, S.: Comparison of black carbon (BC) aerosols in two urban areas - concentrations and size distributions, Atmos. Environ., 35, 2153-2167, 2001.

IPCC: Climate Change 2013: The Physical Science Basis, Contribution of Working Group I to the Fifth Assessment Report of the Intergovernmental Panel on Climate Change, Report, Cambridge University Press, New York, 2013.

Jacobson, M. Z.: A physically-based treatment of elemental carbon optics: implications for global direct forcing of aerosols, Geophys. Res. Lett., 27, 217-220, doi:10.1029/1999GL010968, 2000.

Jaenicke, R.: Atmospheric aerosols and global climate, J. Aerosol Sci., 11, 577-588, 1980.

Junker, C. and Liousse, C.: A global emission inventory of carbonaceous aerosol from historic records of fossil fuel and biofuel consumption for the period 1860-1997, Atmos. Chem. Phys., 8, 1195-1207, doi:10.5194/acp-8-1195-2008, 2008.

Koch, D., Schulz, M., Kinne, S., McNaughton, C., Spackman, J. R., Balkanski, Y., Bauer, S., Berntsen, T., Bond, T. C., Boucher, O., Chin, M., Clarke, A., De Luca, N., Dentener, F., Diehl, T., Dubovik, O., Easter, R., Fahey, D. W., Feichter, J., Fillmore, D., Freitag, S., Ghan, S., Ginoux, P., Gong, S., Horowitz, L., Iversen, T., Kirkevåg, A., Klimont, Z., Kondo, Y., Krol, M., Liu, X., Miller, R., Montanaro, V., Moteki, N., Myhre, G., Penner, J. E., Perlwitz, J., Pitari, G., Reddy, S., Sahu, L., Sakamoto, H., Schuster, G., Schwarz, J. P., Seland, Ø., Stier, P., Takegawa, N., Takemura, T., Textor, C., van Aardenne, J. A., and Zhao, Y.: Evaluation of black carbon estimations in global aerosol models, Atmos. Chem. Phys., 9, 9001-9026, doi:10.5194/acp-9-9001-2009, 2009.

Kuenen, J. J. P., Visschedijk, A. J. H., Jozwicka, M., and Denier van der Gon, H. A. C.: TNO-MACC_II emission inventory; a multi- 
year (2003-2009) consistent high-resolution European emission inventory for air quality modelling, Atmos. Chem. Phys., 14, 10963-10976, doi:10.5194/acp-14-10963-2014, 2014.

Kulmala, M., Asmi, A., Lappalainen, H. K., Baltensperger, U., Brenguier, J.-L., Facchini, M. C., Hansson, H.-C., Hov, Ø., O'Dowd, C. D., Pöschl, U., Wiedensohler, A., Boers, R., Boucher, O., de Leeuw, G., Denier van der Gon, H. A. C., Feichter, J., Krejci, R., Laj, P., Lihavainen, H., Lohmann, U., McFiggans, G., Mentel, T., Pilinis, C., Riipinen, I., Schulz, M., Stohl, A., Swietlicki, E., Vignati, E., Alves, C., Amann, M., Ammann, M., Arabas, S., Artaxo, P., Baars, H., Beddows, D. C. S., Bergström, R., Beukes, J. P., Bilde, M., Burkhart, J. F., Canonaco, F., Clegg, S. L., Coe, H., Crumeyrolle, S., D’Anna, B., Decesari, S., Gilardoni, S., Fischer, M., Fjaeraa, A. M., Fountoukis, C., George, C., Gomes, L., Halloran, P., Hamburger, T., Harrison, R. M., Herrmann, H., Hoffmann, T., Hoose, C., Hu, M., Hyvärinen, A., Hõrrak, U., Iinuma, Y., Iversen, T., Josipovic, M., Kanakidou, M., Kiendler-Scharr, A., Kirkevåg, A., Kiss, G., Klimont, Z., Kolmonen, P., Komppula, M., Kristjánsson, J.-E., Laakso, L., Laaksonen, A., Labonnote, L., Lanz, V. A., Lehtinen, K. E. J., Rizzo, L. V., Makkonen, R., Manninen, H. E., McMeeking, G., Merikanto, J., Minikin, A., Mirme, S., Morgan, W. T., Nemitz, E., O’Donnell, D., Panwar, T. S., Pawlowska, H., Petzold, A., Pienaar, J. J., Pio, C., Plass-Duelmer, C., Prévôt, A. S. H., Pryor, S., Reddington, C. L., Roberts, G., Rosenfeld, D., Schwarz, J., Seland, Ø., Sellegri, K., Shen, X. J., Shiraiwa, M., Siebert, H., Sierau, B., Simpson, D., Sun, J. Y., Topping, D., Tunved, P., Vaattovaara, P., Vakkari, V., Veefkind, J. P., Visschedijk, A., Vuollekoski, H., Vuolo, R., Wehner, B., Wildt, J., Woodward, S., Worsnop, D. R., van Zadelhoff, G.-J., Zardini, A. A., Zhang, K., van Zyl, P. G., Kerminen, V.-M., S Carslaw, K., and Pandis, S. N.: General overview: European Integrated project on Aerosol Cloud Climate and Air Quality interactions (EUCAARI) - integrating aerosol research from nano to global scales, Atmos. Chem. Phys., 11, 13061-13143, doi:10.5194/acp11-13061-2011, 2011.

Lamarque, J.-F., Bond, T. C., Eyring, V., Granier, C., Heil, A., Klimont, Z., Lee, D., Liousse, C., Mieville, A., Owen, B., Schultz, M. G., Shindell, D., Smith, S. J., Stehfest, E., Van Aardenne, J., Cooper, O. R., Kainuma, M., Mahowald, N., McConnell, J. R., Naik, V., Riahi, K., and van Vuuren, D. P.: Historical (1850-2000) gridded anthropogenic and biomass burning emissions of reactive gases and aerosols: methodology and application, Atmos. Chem. Phys., 10, 7017-7039, doi:10.5194/acp10-7017-2010, 2010.

Mareckova, K., Wankmueller, R., Moosmann, L., and Pinterits, M.: Inventory Review 2013: Re- view of Emission Data reported under the LRTAP Convention and NEC Directive, Stage 1 and 2 review, Status of Gridded Data and LPS Data, STATUS Report 1/2013, Umweltbundesamt GmbH, Vienna, Austria, 2013.

McConnell, J. R., Edwards, R., Kok, G. L., Flanner, M. G., Zender, C. S., Saltzman, E. S., Banta, J. R., Pasteris, D. R., Carter, M. M., and Kahl, J. D. W.: 20th-century industrial black carbon emissions altered arctic climate forcing, Science, 317, 1381-1384, 2007.

Meister, K., Johansson, C., and Forsberg, B.: Estimated short-term effects of coarse particles on daily mortality in Stockholm, Sweden, Environ. Health Persp., 120, 431-436, 2012.
Ming, J., Cachier, H., Xiao, C., Qin, D., Kang, S., Hou, S., and $\mathrm{Xu}, \mathrm{J}$.: Black carbon record based on a shallow Himalayan ice core and its climatic implications, Atmos. Chem. Phys., 8, 13431352, doi:10.5194/acp-8-1343-2008, 2008.

Nordmann, S., Birmili, W., Weinhold, K., Müller, K., Spindler, G., and Wiedensohler, A.: Measurements of the mass absorption cross section of atmospheric soot particles using Raman spectroscopy, J. Geophys. Res.-Atmos., 118, 12075-12085, doi:10.1002/2013JD020021, 2013.

Nordmann, S., Cheng, Y. F., Carmichael, G. R., Yu, M., Denier van der Gon, H. A. C., Zhang, Q., Saide, P. E., Pöschl, U., Su, H., Birmili, W., and Wiedensohler, A.: Atmospheric black carbon and warming effects influenced by the source and absorption enhancement in central Europe, Atmos. Chem. Phys., 14, 1268312699, doi:10.5194/acp-14-12683-2014, 2014.

Petzold, A. and Kärcher, B.: Aerosols in the Atmosphere, in: Atmospheric Physics, edited by: Schumann, U., Research Topics in Aerospace, Springer Berlin Heidelberg, 37-53, doi:10.1007/9783-642-30183-4_3, 2012.

Pouliot, G., Pierce, T., van der Gon, H., Schaap, M., Moran, M., and Nopmongcol, U.: Comparing emission inventories and modelready emission datasets between Europe and North America for the AQMEII project, Atmos. Environ., 53, 4-14, 2012.

Pope, C. A., Ezzati, M., and Dockery, D. W.: Fine-particulate air pollution and life expectancy in the united states, N. Engl. J. Med., 360, 376-386, 2009.

Poulain, L., Spindler, G., Birmili, W., Plass-Dülmer, C., Wiedensohler, A., and Herrmann, H.: Seasonal and diurnal variations of particulate nitrate and organic matter at the IfT research station Melpitz, Atmos. Chem. Phys., 11, 12579-12599, doi:10.5194/acp-11-12579-2011, 2011.

Ramanathan, V. and Carmichael, G.: Global and regional climate changes due to black carbon, Nat. Geosci., 1, 221-227, 2008.

Rose, D., Wehner, B., Ketzel, M., Engler, C., Voigtländer, J., Tuch, T., and Wiedensohler, A.: Atmospheric number size distributions of soot particles and estimation of emission factors, Atmos. Chem. Phys., 6, 1021-1031, doi:10.5194/acp-6-1021-2006, 2006.

Saide, P. E., Spak, S. N., Carmichael, G. R., Mena-Carrasco, M. A., Yang, Q., Howell, S., Leon, D. C., Snider, J. R., Bandy, A. R., Collett, J. L., Benedict, K. B., de Szoeke, S. P., Hawkins, L. N., Allen, G., Crawford, I., Crosier, J., and Springston, S. R.: Evaluating WRFChem aerosol indirect effects in Southeast Pacific marine stratocumulus during VOCALSREx, Atmos. Chem. Phys., 12, 3045-3064, doi:10.5194/acp-12-3045-2012, 2012.

Spindler, G., Brüggemann E., Gnauk, T., Grüner A., Müller K., and Herrmann, H.: A four-year size-segregated characterization study of particles $\mathrm{PM}_{10}, \mathrm{PM}_{2.5}$ and $\mathrm{PM}_{1}$ depending on air mass origin at Melpitz, Atmos. Environ., 44, 164-173, 2010.

Spindler, G., Gnauk, T., Grüner, A., Iinuma, Y., Müller, K., Scheinhardt, S., and Herrmann, H.: Size-segregated characterization of $\mathrm{PM}_{10}$ at the EMEP site Melpitz (Germany) using a fivestage impactor: a 6 year study, J. Atmos. Chem., 69, 127-157, 2012.

Spindler, G., Grüner, A., Müller, K., Schlimper, S., and Herrmann, H.: Long-term sizesegregated particle $\left(\mathrm{PM}_{10}, \mathrm{PM}_{2.5}, \mathrm{PM}_{1}\right)$ characterization study at Melpitz - influence of air mass inflow, weather conditions and season, J. Atmos. Chem., 70, 165-195, doi:10.1007/s10874-013-9263-8, 2013. 
Stern, R., Builtjes, P., Schaap, M., Timmermans, R., Vautard, R., Hodzic, A., Memmesheimer, M., Feldmann, H., Renner, E., Wolke, R., and Kerschbaumer: a model intercomparison study focussing on episodes with elevated $\mathrm{PM}_{10}$ concentrations, Atmos. Environ., 42, 4567-4588, doi:10.1016/j.atmosenv.2008.01.068, 2008.

Vignati, E., Karl, M., Krol, M., Wilson, J., Stier, P., and Cavalli, F.: Sources of uncertainties in modelling black carbon at the global scale, Atmos. Chem. Phys., 10, 2595-2611, doi:10.5194/acp-102595-2010, 2010.

Visschedijk, A. and Denier van der Gon, H.: EUCAARI Deliverable: Pan-European Carbonaceous Aerosol Inventory, Report, TNO Built Environment and Geosciences, D42, Utrecht, the Netherlands, 2008.

Wiedinmyer, C., Akagi, S. K., Yokelson, R. J., Emmons, L. K., AlSaadi, J. A., Orlando, J. J., and Soja, A. J.: The Fire INventory from NCAR (FINN): a high resolution global model to estimate the emissions from open burning, Geosci. Model Dev., 4, 625641, doi:10.5194/gmd-4-625-2011, 2011.

Wild, O., Zhu, X., and Prather, M. J.: Fast-J: accurate simulation of in- and below-cloud photolysis in tropospheric chemical models, J. Atmos. Chem., 37, 245-282, 2000.
Yang, Q., W. I. Gustafson Jr., Fast, J. D., Wang, H., Easter, R. C., Morrison, H., Lee, Y.-N., Chapman, E. G., Spak, S. N., and Mena-Carrasco, M. A.: Assessing regional scale predictions of aerosols, marine stratocumulus, and their interactions during VOCALS-REx using WRF-Chem, Atmos. Chem. Phys., 11, 11951-11975, doi:10.5194/acp-11-11951-2011, 2011.

Zhang, Y., Sartelet, K., Zhu, S., Wang, W., Wu, S.-Y., Zhang, X., Wang, K., Tran, P., Seigneur, C., and Wang, Z.-F.: Application of WRF/Chem-MADRID and WRF/Polyphemus in Europe - Part 2: Evaluation of chemical concentrations and sensitivity simulations, Atmos. Chem. Phys., 13, 6845-6875, doi:10.5194/acp-136845-2013, 2013.

Zaveri, R. A. and Peters, L. K.: A new lumped structure photochemical mechanism for largescale applications, J. Geophys. Res., 104, 30387-30415, 1999.

Zaveri, R. A., Easter, R. C., Fast, J. D., and Peters, L. K.: Model for Simulating Aerosol Interactions and Chemistry (MOSAIC), J. Geophys. Res., 113, D13204, doi:10.1029/2007JD008782, 2008. 